\title{
Göçmen İşçilerin İSG Faktörlerinin İncelenmesi, Sonuçlar Üzerinde Tartışma ve Öneriler: Kapsam Belirleme Derlemesi
}

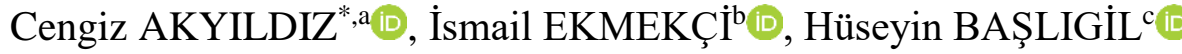 \\ $a^{*}$ Istanbul Ticaret Üniversitesi, İŞS Sağllğı ve Güvenliği Bölümü, 34134, ISTANBUL, TÜRKIYE \\ ${ }^{b}$ Istanbul Ticaret Üniversitesi, Endüstri Mühendisliği Bölümü, 34134, ISTANBUL, TÜRKIYE \\ c İstanbul Esenyurt Üniversitesi, Endüstri Mühendisliği Bölümü, 34134, ISTANBUL, TÜRKIYE
}

\begin{tabular}{l} 
MAKALE \\
BİLGISI \\
\hline $\begin{array}{l}\text { Alınma: 07.04.2020 } \\
\text { Kabul: 11.07.2020 }\end{array}$ \\
\hline Anahtar Kelimeler: \\
Göçmen ve sığınmacı \\
işçiler, İş Sağlığı ve \\
Güvenliği, Meslek \\
hastalıkları, İş \\
kazaları, Çalışma \\
şartları, \\
*Sorumlu Yazar: \\
e-posta: \\
cengiz9299@hotmail.c \\
om
\end{tabular}

ÖZET

Bu çalışmanın temel amacı, göçmen, mülteci ve sığınmacı işçilerin İş Sağlı̆̆ı ve Güvenliği (ISSG) faktörleri literatürünü özetlemektir. 2007-2019 yılları arasında yayınlanan çalışmalar için ResearchGate, Simon Fraser University, UK Audit Commission, ScienceDirect, SSRN, academia.edu, Hacettepe Üniversitesi, SAGE, SemanticScholar, Middlesex University London, Scopus, Scopus, ProQuest Dissertations \& Theses GlobalPub, Web of Science veri tabanların araştırarak bir kapsam incelemesi gerçekleștirdik. Çalışma 5 nicel, 12 nitel ve 3 karma metodoloji ile yapılmıştır. Temel bulgular, yerlilere kıyasla, göçmen ve sığınmacı çalışanların daha düşük vasıflı işlerde çalıştığını, işyerinde algılanan ayrımcılığın yaygın olduğunu; daha uzun süreler çalışma talep edildiğini, daha kötü çevresel çalıșma koşulları, daha fazla mesleki risklere maruz kaldığını (örneğin, fiziksel, kimyasal, ergonomik ve psikososyal tehlikeler); mesleki yaralanma riskinin daha yüksek olduğunu; daha kötü genel ve zihinsel sağlık durumları olduğunu; ücretlerini gereği üzere alamadıklarını, sağlı hizmetlerine gerektiği gibi erişemediklerini göstermektedir. Mevcut inceleme bulguları, göçmen ve sığınmacı çalışanların olumsuz İSG faktörlerinin iyileştirilmesini ve sağlık hizmetlerine adil erişimin garanti edilmesini sağlamak için bütüncül bir küresel uzlaşmaya ihtiyaç olduğunu göstermiş̧ir. Çözüm prosesi, işyerinde mesleki risk faktörlerini ve ilişkili olumsuz sonuçları önlemek ve izlemek için somut ve kanıta dayalı bir yaklaşım gerektirecektir.

\section{Examination of OHS Factors of Migrant Workers, Discussion on Results and Suggestions: A Scoping Review}

\author{
ARTICLE \\ INFO \\ Received: 07.04.2020 \\ Accepted: 11.07.2020 \\ Keywords: \\ Migrant and refugee \\ workers, Occupational \\ Health and Safety, \\ Occupational diseases, \\ Occupational \\ accidents, Working \\ conditions, Review \\ *Corresponding \\ $\underline{\text { Authors }}$
}

\begin{abstract}
The main purpose of this study is to summarize the existing literature on Occupational Health and Safety (OHS) of migrant, refugee and asylum-seeking workers. Simon Fraser University, UK Audit Commission, SSRN, Hacettepe University, SAGE, SemanticScholar, Middlesex University London, Scopus, Scopus, ProQuest Dissertations \& Theses GlobalPub, Web of Science for studies published between 2007-2019 We conducted a scope review by researching databases. The study was carried out with 5 quantitative, 12 qualitative and 3 mixed methodologies The main findings are that immigrant and asylum-seekers work in lower-skilled jobs compared to the locals, and perceived discrimination in the workplace is widespread; longer work is demanded, poorer environmental working conditions are exposed to more occupational risks (eg physical, chemical, ergonomic and psychosocial hazards); the risk of occupational injury is higher; worse general and mental health conditions; It shows that they could not get their fees properly and access health services properly. The current review findings have shown that a holistic global consensus is needed to ensure that the negative OSH factors of immigrant and asylum-seeker workers are improved and that fair access to health services is guaranteed. The solution process will require a
\end{abstract}

Bu makaleye atıf yapmak için C. Akyıldız, İ. Ekmekçi ve H. Başlıgil, "Göçmen İşçilerin İSG Faktörlerinin İncelenmesi, Sonuçlar Üzerinde Tartışma ve Öneriler: Kapsam Belirleme Derlemesi," Gazi Mühendislik Bilimleri Dergisi, cilt 6, sayı 2, s. 145-159, Ağustos, 2020, doi: https://dx.doi.org/10.30855/gmbd.2020.02.07. 
e-mail:

cengiz9299@hotma

il.com concrete and evidence-based approach to prevent and monitor occupational risk factors and associated negative outcomes at the workplace.

\section{GİRISS (INTRODUCTION)}

Uluslararası Çalışma Örgütü (ILO) 2017 son tahminlerine göre, dünya çapında yaklaşık 258 milyon uluslararası göçmen, 234 milyon çalışma çağındaki göçmen (15 yaş ve üstü), 164 milyon göçmen işçi var; bunların 95,7 milyonu erkek ve 68,1 milyonu kadındır. Genel olarak, çalışma çağındaki göçmenler 15 yaş ve üstü küresel nüfusun yüzde 4,2'sini, göçmen işçiler ise tüm çalışanların yüzde 4,7'sini oluşturmaktadır. Hedef ülkelerde, göçmen işçilerin küresel işgücü içinde, çalışma çağındaki küresel nüfustan daha yüksek payı, göçmen olmayanlara (yüzde 61,6) göre göçmenlerin işgücüne katılım oranının daha yüksek olmasından (yüzde 70,0) kaynaklanmaktadır [1]. Uluslararası göçmenlerin Dünya Sağlık Örgütü (WHO) Avrupa Bölgesi'ndeki 53 ülkede nüfusun yaklaşık \%10'unu (90,7 milyon) temsil ettiği ve bu Bölgedeki tüm çalışanların yaklaşık\%12'sinin göçmen olduğu tahmin edilmektedir [2].

Dünya genelinde düzensiz göçmen sayısı giderek artmaktadır ve günümüzde toplam göçün yaklaşık \%15'inin düzensiz koşullar altında gerçekleştiği tahmin edilmektedir [3]

Coğrafi ve ekonomik konumundan ötürü, Suriye başta olmak üzere, Afganistan, Irak, Gürcistan, İran ve Türk Cumhuriyetleri, Afrika, Doğu Avrupa ülkelerinden Türkiye'ye son dokuz yılda altı milyona yakın (İçişleri Bakanlığı Göç İdaresi kayıtlarına göre Türkiye'de bulunan yabancilarin saylsı hakkinda 08.11.2019 tarihli bakanlik açılklaması) göçmen, mülteci, sığınmacı ve düzensiz göçmen bulunmaktadır. Bakanlık açıklamasına göre 2019 yılı sonu resmi kayıtlarına göre Türkiye'de 5.074.908 yabancının bulunduğu yönündedir. ILO ortalama hesaplamalarına [3] göre sayıları tespit edilemeyen kayıt dışı düzensiz göçmenleri eklersek toplam sayı yaklaşık 5.970.480 civarına gelmektedir. Dolayısıyla, ulusal nüfusun \%7'si kadar, yaklaşık 6 milyon uluslararası göçmen bulunmaktadır. Türkiye'de bulunan sadece Suriyelilerin sayıs1, resmi rakamlara göre 3.576.644 kişidir. Bunların 1.654.116 kişisi kadın, 1.922.228 kişisi erkektir. Bu nüfusun çalışma yaşında olanların sayısı (15-64 yass) 936.346 kadın, 1.167.562 erkek olmak üzere toplam çalıșabilir Suriyeli nüfusu 2.103.908 kişidir. Çalışabilir Suriyeli nüfusunun toplam Suriyeli nüfusuna oran1 \%58'dir (14.02.2020 tarihi itibarlyla, Göç İdaresi Genel Müdürlüğü istatistik verisi). Türkiye'de bulunan toplam yabancıların sayısı üzerinden hesapladığımızda çalışma yaşındaki toplam yabancı sayısının yaklaşı 3.462 .878 kişi olduğu görülür [4].

Türkiye'deki istihdam oranlarına bakarsak; toplam nüfus Türkiye İstatistik Kurumu (TÜIK), Adrese Dayalı Nüfus Kayıt Sistemi 2019 Sonuçlarına göre 83 milyon 154 bin 997 kişiye ulaştı. Türkiye'de 15-64 yaş aralığındaki toplam nüfus 56.391 .925 kişi ve bunun 28.524.329 kişisi erkek, 27.867.596 kişisi kadınlardan oluşmaktadır. İstidama katılım oranının \%67 olması mümkün iken, reel katılım oranı 15-64 yaş aralığı nüfusun sadece \%53'üdür [5]. Yukarıdaki bilgiler 1şığında görüyoruz ki göçmen, mülteci, sığınmacı, uluslararası koruma altındakiler ve düzensiz göçmenlerin istihdama katılım oranı yerli çalışanlardan $\% 5$ daha yüksek. $\mathrm{Bu}$ durum menşei ülkenin dışındakilerin yaşamlarını sürdürme kaygılarını açıklamaktadır.

Yabancı çalışanlar, içinde bulundukları zor koşullar nedeniyle, genellikle yerli halkın yapmak istemediği fiziksel güce dayalı, niteliksiz, güvencesiz ve düşük ücretli işler yapmaktadırlar. Ayrıca yerel çalışanlardan daha uzun saatler ve daha kötü koşullarda çalışmaktadırlar. Uluslararası literatürde "3D işler" denen tehlikeli, kirli ve aşağılayıcı (dangerous, dirty, demeaning) olarak adlandirılırlar. $\mathrm{Bu}$ sebeple, hem mesleki yaralanma ve hastalık riski daha yüksektir hem de yerlilerden daha fazla olumsuz mesleki maruziyet oranlarına sahiptirler $[6,10,11]$.

Göçmen ve mülteci işçilerin çoğu, ağır fiziksel iş yükü, yaralanma riski, toksik maddelere maruziyet veya ağır psikososyal risk etmenlerine (örn. yüksek zihinsel iş yükü, olumsuz sosyal etkileşimler, ücret sorunları, mobbing) maruz kalan işlerde çalışmaktadır. Bu nedenle, göçmen ve mülteci işçilerin iş sağlığı ve güvenliği sorunları tüm dünyada halk sağlığının çok önemli bir parçasıdır.

Daha önceki çalışmalar göstermektedir ki yerlilere kıyasla göçmen işçiler:

1. Güvencesiz ve sözleşmesiz koşullarda işe alınmakta, düşük vasıflı işlerde çalıştırılmaktadır.

2. Çalışma alanları tehlikeli işlerde yoğunlaşmıştır.

3. Mesleki yaralanma ve hastalık riski daha yüksektir.

4. Gelirleri açlık sınırının çok altındadır.

Diğer ülkelerde de olduğu gibi, özel ve kayıt dışı ev işçilerine ve bakıcılara yönelik talebin artmasıyla, sosyal koruma ve haklara tam erişimi olmayan bir yabancı çalışan kadın varlığı bulunmaktadır. 
Bu çalışmanın amacı;

1. Kapsam ve gözden geçirme yoluyla mevcut literatürü özetlemek

2. Geçmişteki ve mevcut durumu analiz etmek ve 3. Göçmen mülteci işçiler arasında iş sağlı̆̆ ve güvenliği ile ilgili gelecekteki araştırmalara yönelik önerilerde bulunmaktır.

Aşağıdaki nedenlerle göçmen çalışanlara odaklanmaya karar verdik:

1. Göçmen işçilerin İş Sağlığı ve Güvenliğ konusundaki eski sistematik ve kapsam belirleme incelemeleri yeterince ele alınmamıştır [7,9,11-13]; ve 2. Ekonomik olumsuzluklar, iklim değişikliği ve savaşlar gibi nedenlerden dolayı ekonomisi ve güvenliği yüksek ülkeler üzerinde öngörülemez bir göç baskısı yaratmıştır, sosyal sorunlara neden olmuş, olumlu ve olumsuz ekonomik etkiler getirmiştir $[3,4,14]$.

\section{YÖNTEMLER (METHODS)}

Literatürdeki yöntemleri kullanarak bir kapsam incelemesi yaptık ve Tablo 2'de gruplandırdık [7,9,1517].

\subsection{Arama Stratejisi (Search Strategy)}

2007-2019 yılları arasında yayınlanan çalışmalar için Simon Fraser University, UK Audit Commission, SSRN, academia.edu, Hacettepe Üniversitesi, Ebsco, SAGE, SemanticScholar, Middlesex University London, Scopus, Scopus, ProQuest Dissertations \& Theses GlobalPub, Web of Science veri tabanların araştırarak bir kapsam incelemesi gerçekleştirdik.

Veri tabanlarında göçle ilgili terimleri, sonra iş sağlığı ve güvenliği ile ilgili terimleri taradık:

Arama 1: (Göç tanımları) anahtar kelimeler: Göç (Migration) OR Göçmen (Immigrant) OR Mülteci (Refugee) OR Göçmen işçi (Migrant worker) OR Kadın Göçmen İşçi (Female Migrant Worker) OR Göçmen Tarım İşçisi (migrant agricultural worker)

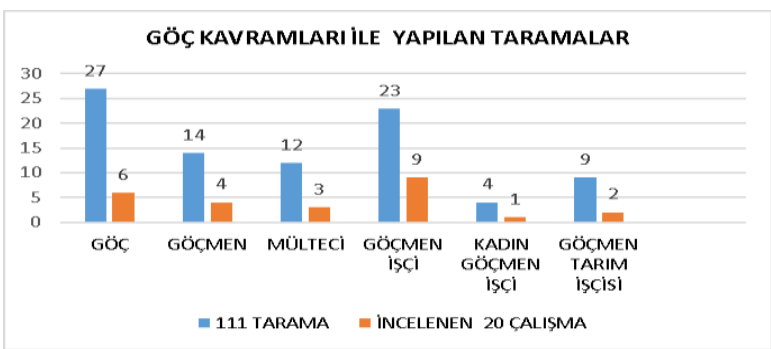

Şekil 1. Göç tanımları ile yapılan taramalar (Scans with migration definitions)

Arama 2: (İş sağlığı ve güvenliği tanımları) anahtar kelimeler: İş (Work) OR İstihdam (Employment) OR
Eğitim (Training) OR Mesleki (Occupational) OR İş Sağlığ 1 (Occupational Health and Safety) OR Mesleki Hastalıklar (Occupational Diseases) OR İş kazası (Occupational accident),

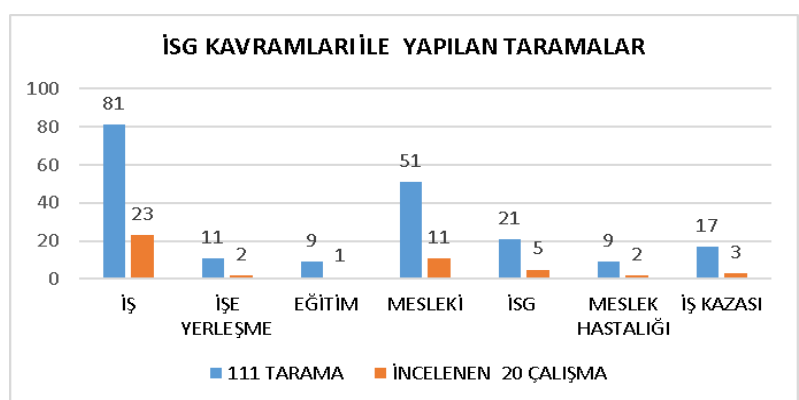

Şekil 2. ISG tanımları ile yapılan taramalar (Scans with OHS definitions)

\subsection{Seçim / Hariç Tutma Kriterleri Ve Değerlendirme (Inclusion/Exclusion Criteria And Assessment)}

Başlıklar ve özetler, esas olarak, aşağıdaki inceleme kriterlerini karşılamayanları hariç tutmak için tarandı: hakemli bilimsel dergilerde İngilizce veya Türkçe olarak yayınlanan göçmenler ve İş Sağlığı ve Güvenliği konularına odaklanmış ve göçmenlere odaklanan orijinal makaleler, raporlar ve tezler saptanmıştır.

Daha sonra, ilgili tüm makaleler tam olarak okundu ve aşağıdaki kriterler uygulanarak ikinci bir seçim yapıldı: taranan nitel, nicel ve karma çalışmalar;

(a) göç, iş ve sağlık arasındaki ilişki, (b) göçmen işçiler arasında iş sağlığı ve güvenliği, (c) göçmen işçilerin sağlık durumu, (d) istihdam edilen göçmenler arasında gerçekleştirilen önleyici programlar / faaliyetler,

(e) göçmen işçiler arasında sağlık ve güvenliğin sosyal, mesleki, kültürel ve / veya ekonomik belirleyicileri,

(f) göçmen işçiler arasında sağlık hizmetlerine erişim ve bu hizmetlerin kullanımı.

Son olarak, dâhil edilen çalışmaların her biri, çalışmanın ana özellikleri (yazarlar, yıl ve dergi) dahil olmak üzere bir dizi parametre kullanılarak değerlendirildi; çalışmanın ülkesi, amacı, tasarımı ve dönemi; bilgi toplama tekniği, katılımcıların özellikleri (örneklem büyüklüğü, cinsiyet, yaş, dahil etme / hariç tutma kriterleri, varsa karşılaştırma grubu), ana sonuçlar, sınırlamalar (varsa); ve sonuçlar.

\section{SONUÇLAR (RESULTS)}

Sonuç çıktıları raporlanmayanlar ve kopya çalışmalar kaldırdıktan sonra, toplam 111kayıt belirledik. 


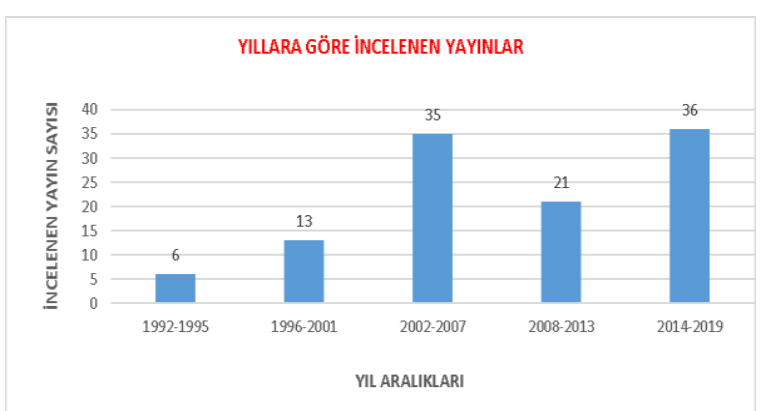

Şekil 3. Yillara göre incelenen yayınlar (Publications examined by years)

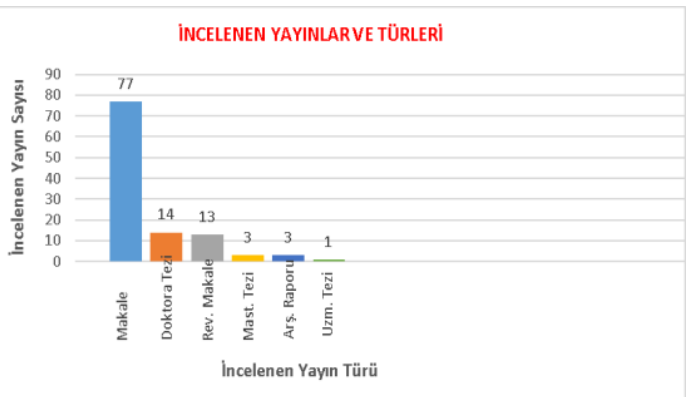

Şekil 4. İncelenen yayınlar ve türleri (Publications reviewed and their types)

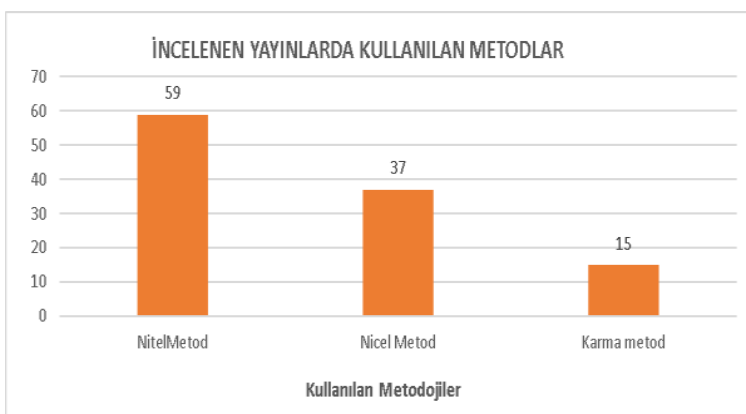

Şekil 5. Incelenen yayınlarda kullanılan metotlar (Methods used in the publications)

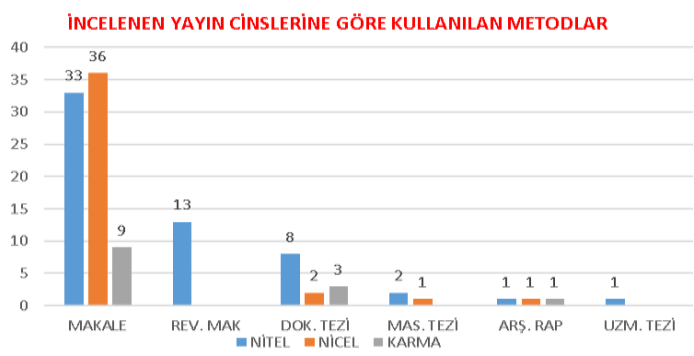

Şekil 6. İncelenen yayın cinslerine göre kullanılan metotlar (Methods used by publication types)

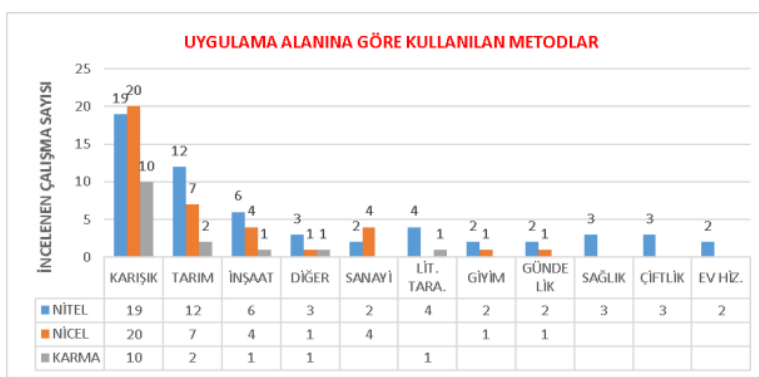

Şekil 7. Uygulama alanına göre kullanılan metotlar (Methods used by application area)

Daha sonra, bu potansiyel olarak alakalı çalışmaların 91 tanesi taramada başlıklara ve özetlere dayanarak elendi ve 20 çalışma dâhil edildi.

İncelenen 20 çalışmanın on iki tanesi nitel [2, 4, 6, 7, 9, $11,12,16-20]$, beş tanesi nicel [5, 8, 10, 13, 14], üç tanesi karma $[1,3,15]$ çalışmalardır.

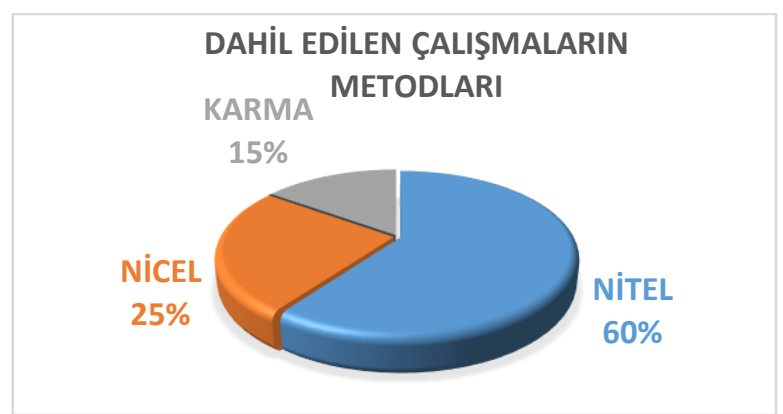

Şekil 8. Dahil edilen çalışmaların metotları (Methods of the included studies)

Çalışmaların \%75'i $[1-3,5,6,8-13,15,17,18,20]$ kesitsel, \%25'i [4, 7, 14, 16, 19] uzunlamasına çalışma idi.

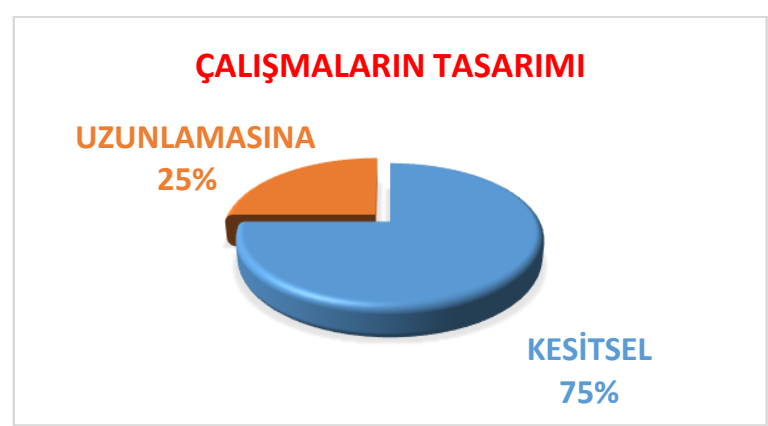

Şekil 9. Çalışmaların tasarımı (Design of studies)

Çalışmaların \%25'i $[3,7,14,16,20]$ nesnel verilere, \%75'i [1, 2, 4-6, 8-13, 15, 17-19] subjektif (anket, görüşme vs.) verilere dayanmaktadır. 


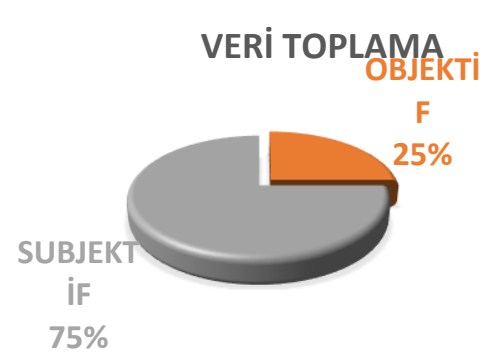

Şekil 10. Veri toplama nitelikleri (Data collection features)

İncelenen çalışmalar, nitel, nicel ve karma metodolojilerin tümünü kapsamaktadır. Nitel çalışmalar, gözlem, görüşmeler ve belge analizi gibi nitel veri toplama yöntemlerinin kullanıldığ 1 , genellikle algılara dayalı ve olayların doğal ortamda işleyiş̧i çerçevesinde ortaya konmasına yönelik süreçlerin izlendiği araştırma türüdür (Arslan, 2012). Nicel çalışmalar, olayları nesnelleştirerek gözlemlenebilir, ölçülebilir ve sayısal olarak ifade edilebilir bir şekilde ortaya koyan, gözlem ve ölçmelerin tekrarlanabildiği ve objektif yapıldığı araştırma türüdür (Arslan, 2012). Karma araştırma yöntemleri, araştırmacının bir çalışma veya birbirini izleyen çalışmalar içerisinde nitel ve nicel yöntem ile yaklaşım ve kavramları birleştirmesi olarak tanımlanır. Kesitsel çalışmalar belirli kısa zamanda, zaman faktörünün verilere etki edemediği süreli çalışmalardır. Uzunlamasına çalışmalar ise, geriye ve ileriye yönelik, uzun zaman diliminde, verilerin üzerinde zaman etkisinin var olduğu çalışmalardır.

Tablo 1. Göçmen işçilerin iş sağllğ ve güvenliği ile ilgili kapsam incelemesinde yer alan 20 çalışmanın temel özelliklerinin özeti (2007-2019) (Summary of the key features of the 20 studies included in the scope review of migrant workers of migrant workers on occupational health and safety (2007 2019)

\begin{tabular}{|l|c|}
\hline DEĞiŞKEN \\
\hline ÇALIŞMANIN TÜRÜ & $12(\% 60)$ \\
\hline NİTEL & $5(\% 25)$ \\
\hline NİCEL & $3(\% 15)$ \\
\hline KARMA & $15(\% 75)$ \\
\hline ÇALIŞMANIN TASARIMI & $5(\% 25)$ \\
\hline KESİTSEL & $3(\% 15)$ \\
\hline UZUNLAMASINA & $1(\% 5)$ \\
\hline ÇALIŞMALARIN TARIHLERİ & $1(\% 5)$ \\
\hline 2007 & $3(\% 15)$ \\
\hline 2011 & $2(\% 10)$ \\
\hline 2012 & $2(\% 10)$ \\
\hline 2013 & $4(\% 20)$ \\
\hline 2014 & $1(\% 5)$ \\
\hline 2015 & $3(\% 15)$ \\
\hline 2017 & $15(\% 75)$ \\
\hline 2018 & $5(\% 15)$ \\
\hline 2019 & \\
\hline VERI TOPLAMA YÖNTEMLERİ & \\
\hline $\begin{array}{l}\text { Anket, yüz yüze görüşme, grup } \\
\text { görüşme }\end{array}$ & \\
\hline $\begin{array}{l}\text { Nesnel veriler (istatistik veriler, kaza } \\
\text { kayıtları, vaka listeleri) }\end{array}$ & \\
\hline
\end{tabular}


çoğu birden fazla güvenlik açı̆̆ı yaşamaktadır, göçmen işçiler için; İSG ile ilgili yeterli politika ve prosedür oluşturulmaması, işyerinin kötü çalışma koşulları ve güvenli olmayan durumlar içermesi, İSG ve işyerindeki hakları konusunda sınırlı bilgiye sahip olmaları ve çalışma koşulları ile tehlikelerin bildirilmemesi ve İSG sorunlarına yanıt verilmemesi, bu güvenlik açıklarını oluşturur. [17]. İşverene bağımlılık, güvenlik açığını artırır ve çalışanın gücünü azaltır, İşçilerin işverenlerine bağımlı olmalarının, göçmenlik sürecindeki rolü nedeniyle, işçi sesinin susturulmas etkisine sahip olduğunu ve bunun iyi mekanizmalarla ele alınması gerektiği anlaşılmıştır, kayıt dışı göçmen işçilerin tamamı kayıt altına alınmalıdır [18]. İş dünyası, yeni teknolojilerin dönüştürücü etkisiyle, demografik ve iklim değişikliği ile yeşil ekonomiye geçiş gibi derin değişimler geçiriyor, bu değişiklikler, dünya çalışanlarının güvenliği ve sağlığı için yeni zorluklar ve yeni firsatlar getirecektir [19]. Küresel güçlerin ekvatorun altındaki ülkelerde yarattığ karışıklıkların sonucunda göçmenler için hedef ülkelerde de global güçler göçmen işçiler için sorun oluşturmaya devam ederler, sürekli bir kaos ve tedirginlik ortamı sürer gider, bu baskılar işçilerin sağlık hizmetlerine erişimini de baskılar, bu olumsuzluk işçilerin sağlıklı ve tehlikesiz bir işyerinde çalışma hakkını sınırlandıran ve zayıflatan politik ve ekonomik düzenleyiciler tarafından hesaba katılmalıdır [20].

3. İSG eğitimi, mesleki eğitim, dil, iletişim, sağlık desteği $[2,4,6,11,17]$ :

Yaralanmaları azaltmak için eğitimcilerin tam zamanlı olarak ișe alınmasını gerekir, eğitimin etkisiz olmasının en önemli nedeni zayıf dil becerisidir [2]. İş kazalarını ve hastalıklarını önlemek için hem göçmenlere hem de işverenlerine pratik destek sağlanmalıdır. Göçmen işçilere, özellikle iş kazaları ve meslek hastalıkları ile ilgili olarak, ücretsiz ya da oldukça sübvanse edilen tıbbi hizmetlere erişim sağlanmalı [4]. Çalışanların örgün eğitim düzeyi ve temel dil bilgisi, sağlık ve güvenlik eğitimi için de önemlidir, çalışanların sağlık hizmetlerinin dokümantasyonu tutulmalıdır [6]. Sağlık hizmetlerinin göçmen nüfusa erişimini arttırmaya yönelik çabalar, göçmen işçilerin refahını da artıracaktır, ortak dilin rolü asla inkâr edilemez, göçmen nüfusun dil becerileri ile donatılması bilgiye ulaşmalarını kolaylaştırır ve İSG hizmetlerine erişilebilirliği artırır [11]. Güvenli çalışma entegrasyonunun başarısı, iş bulmadan önce hakları hususunda bilgi sağlamaya, uygun iș eğitimi sağlamaya ve yaralanmaların önlenmesine ilişkin eğitim toplantılarına katılmaya teşvik edilmesine bağlıdır [17]

4. Gözetim sistemi, belgelendirme ve İSG'ne erişim zorlukları $[6,11]$ :
Mesleki yaralanmalar ve hastalıklar için gözetim sistemi kurulmalıdır, Çalışanların sağlık hizmetlerinin dokümantasyonu tutulmalıdır [6]. Göçmen işçilerin İş Sağlığ 1 ve Güvenliği hizmetlerine erişiminde karşılaştıkları zorluklar baş edilmez ve çok yönlüdür [11].

5. Psikososyal riskler, cinsel taciz, düşük ücret, tazminat, sömürü, iş sözleşmeleri sorunu, baskı [4, $7,9,12,16,18]$ :

Göçmen işçiler de dahil olmak üzere tüm işçilerin toplu olarak örgütlenmesine izin verilmeli, göçmen işçilerin, yerli çalışanlar gibi, eşit ücret, izin ve tazminat haklarından yararlanmaları sağlanmalı, göçmen işçilerin de anlaşmazlık yaşandığında işverenini değiştirme hakkı verilmelidir [4]. Göçmen çiftçilerin işgücü, sağlık, psikososyal ve ücret koşulları ile ilgili araştırma eksikliğine dikkat çekilmelidir [7]. Mülteciler ve insan ticareti kurbanları ile ilişkili olarak devletlerin ve uluslararası örgütlerin, uluslararası insan hakları yasalarını temel alarak sürdürülebilir çözümler üretmek için birleşmelerinin gerekliliği belirtilmelidir [9]. Bazı işverenler, ev işçilerinin kırılganlıklarından yararlanmaktadır, çünkü yasalar buna izin vermektedir. İşverenler, ev işçilerinin sağlık ve güvenliği ile ilgilenmek zorunda değildir, çünkü hane halkları sağlık ve güvenlik yasasından muaftır. Ayrıca, iş kanunu, işverenlerin ev işçilerine sürekli olarak asgari ücrete göre ödeme yapmalarına izin veriyor [12]. Çok sınırlı pazarlık gücü nedeniyle, göçmen işçiler İSG haklarını etkin bir şekilde savunamamaktadırlar, özellikle yazılı sözleşmelerin yokluğunda, bir iş ilişkisinin varlığını kanıtlamada göçmen işçilerin karşılaştıkları engelleri ortadan kaldırmak için yenilikçi yollar aranmalıdır, ortak ISG komitelerinin kurumsallaştırılması ve sendikalarda reform yapmak yoluyla toplu pazarlık mekanizmalarının güçlendirilmesi sağlanabilir [16]. İşverene bağımlılık, güvenlik açığını artırır ve çalışanın gücünü azaltır, İSG uygulamalarını ve düzenleyici etkinliği zayıflatan önemli faktörler, göç programlarını yöneten devlet kurumları ile istihdam standartlarını düzenleyen yasalar ve işçi tazminatı ve iş sağlığı ve güvenliği de dahil olmak üzere, iş mevzuatına uymaktan sorumlu taşra kurumları arasındaki iletişim yetersizlikleridir [18].

\subsection{Nicel Çalıșmalar (Quantitative Studies)}

Tablo 2'de 5 nicel çalışmanın [5, 8,10,13, 14] temel özellikleri, dört kesitsel nitel çalışma $[5,8,10,13]$ ve bir uzunlamasına çalışma çerçevesinde [14] gösterilmektedir.

Araştırma sorusuna dayanarak, nicel çalışmaları aşağıdaki üç ana grup altında toplayabiliriz: 
1. İSG kavramı, yasal gereklilik ve uygulamalar, devlet düzenlemeleri, tarafların karşılıklı hak ve sorumlulukları, global uygulamalar ve sorunları [5, $8,10,13]$ :

30 yaşın altındaki işçilere odaklanarak, mesleki eğitime erişim sağlamak için göçmen işçi çalıştıran işletmeler üzerinde denetimlerin tavsiye edilir [5]. Göçmen kadın işçiler temel haklardan yoksundurlar. Yazılı kadın hakları uygulamaları kendilerine ulaşmıyor, göçmen kadın işçilerin sorunlarının çözümü için acil bir çalışmaya ihtiyaç vardır. Hükümete ve STK'lara göçmen kadın işçilerin haklarını korumak ve iyileştirici önlemler almalarında yardımcı olacak tespitler yapıldı [8]. Tüm işyerlerinde asgari uygun ve adil bir yaşam koşulu sağlanmalıdır, yasal düzenlemelere ve mevzuatın uygun şekilde uygulanmasına, göçün itici faktörlerinin kontrol altına alınmasına acil ihtiyaç vardır [10]. Çalışma sözleşmeleri sırasında tüm göçmen işçilere sağlık hizmetleri sigortası sağlanmalıdır [13].

2. İSG eğitimi, mesleki eğitim, dil, iletişim, sağlık desteği $[5,10,13,14]$ :

Mesleki eğitim, göçmen işçiler arasındaki mesleki yaralanmaların azaltılmasında birinci sıradadır, uzun süre çalışanların mesleki yaralanma olasılığı daha fazladır [5]. Sağlık hizmetleri, eğitim ve diğer tüm sosyal güvenlik önlemleri, yalnızca göçmen işçiler için değil, aile üyeleri için de hesaplı ve erişilebilir olmalıdır [10]. Katar'daki göçmen işçiler sırt ağrısı, baş ağrısı, kalp ve solunum yolu hastalıkları gibi kardiyopulmoner, GI abdominal, ishal, peptik ülser, yorgunluk, depresyon, anksiyete, stres ve diyabet, hipertansiyon ve astım ve alerjik hastalıklar gibi sağlık sorunları yaşamaktadırlar, en yaygın iş kazası, düşme, kayma ve cisim çarpmasıdır, göçmen işçilerin neredeyse \%80'inde sağlık sigortası yoktur [13]. Çalışmaların çoğunun işçilerin özelliklerini tanımladığını ve bazılarının da işyeri özellikleri ve göçmenlerin genel sağlık durumu ile ilgili olduğunu göstermektedir [14]

3. Psikososyal riskler, cinsel taciz, düşük ücret, tazminat, sömürü, iş sözleşmeleri sorunu, baskı $[5,8]$ :

İş sözleşmesinin mesleki yaralanma üzerinde de önemli etkisi vardır, cinsiyet, mesleki yaralanmalarda önemli bir etkiye sahiptir [5]. Göçmen kadın işçiler temel haklarından mahrumdurlar ve işverenleri tarafından sömürülmektedirler [8].

\subsection{Karma Çalışmalar (Mixed Studies)}

3 karma çalışmanın $[1,3,15]$ temel özellikleri, Tablo 2 'de gösterilmektedir.

1. İSG eğitimi, mesleki eğitim, dil, iletişim, sağlık desteği [1]: Eğitimlere katılım için küçük teşvikler sunulmalı, seyahat / eğitim sürelerinde ödeme yapılması, toplantılardaki yemekler katılımcıları cezbeder ve grup bağını güçlendirir, eğitim toplantılarının ardından sosyal medyayı kullanarak sürekli iletişim sağlanmalı [1]

2. İSG kavramı, yasal gereklilik ve uygulamalar, devlet düzenlemeleri, tarafların karşılıklı hak ve sorumlulukları, global uygulamalar ve sorunları [3]: Bölgesel ve ulusal ortak çalışma yapılmalı, veri ve istihbarat paylaşımı, iyileştirilme çalışmaları, istihdam ve konut standartlarının kolay ve sürekli olması, sosyal hizmetlerin aksamaması, yerel gerilimleri en aza indirme, sosyal uyumu geliştirme gibi çalışmalara önem verilmeli [3].

3. Psikososyal riskler, cinsel taciz, düşük ücret, tazminat, sömürü, iş sözleşmeleri sorunu, bask1[15]: Asya ekonomik bölgesinde kadın göçmen işçiler ciddi zorluklar yaşamakta, iyi ve eşit çalışma koşullarından yararlanamamaktadırlar, kadın göçmen işçilerin karşılaştıkları zorlukları, taciz ve güvensizlikleri azaltmak için cinsiyete özgü eylemlere ve çözümlere ihtiyaç vardır; sağlık, eğitim ve adalete erişimi güvence altına alırken, ekonomik ve sürdürülebilir büyümeden yararlanma becerilerini geliştirmek gerekir [15].

\section{TARTIŞMA (DISCUSSION)}

Araştırma kapsamı çerçevesinde incelenen ve Tablo 2'de sunulan yirmi adet çalışmanın inceleme sırasına göre bulguları ve çözüm önerileri şunlardır:

1. Mesleki yaralanma riskini azaltmak için gerekli eğitimlerin verilmesi, durum değerlendirmesi yapılması ve süreklilik sağlanması [6],

2. Mevsimlik Meksikalı tarım işçileri çalıştıran İngiliz Kolombiyalı çiftçilerin İş Sağlığı ve Güvenliği ve barınma uygulama sorunları [7],

3. İngiltere'deki göçmen işçilerin İSG koşullarının 2007 y1l takibi [8],

4. Beş Asya ve Pasifik ülkesinde (Avustralya, Kore Cumhuriyeti, Malezya, Singapur ve Tayland) göçmen işçilere İş Sağlığı ve Güvenliği uygulamaları konusunda artan endișeye yanıt olarak İș Sağlığı ve Güvenliği (İSG) koşullarını incelenmesi [9],

5. Bireysel faktörlerin, mesleki eğitimin ve çalışmanın göçmen işçilerin mesleki yaralanmaları üzerindeki etkisinin belirlenmesi [10], 
6. Tarım, ormancılık ve balıkçılık sektörlerinde mesleki maruziyetleri, veri kısıtlarını, göçmen işçilerin özelliklerini, göçmen işçilere yönelik endişe nedenlerinin, incelenmesi [11,

7. Kapsamlı bir literatür taraması yaparak tarımdaki göçmen işçiler hakkında mevcut bilgilerin derlenmesi ve sinıflandırılması [12],

8. Thamil Karur bölgesinde Thogamalai maden ocaklarında çalışan göçmen kadın işçilerin İş Sağlığı ve Güvenliği sorunları [13],

9. Türkiye'ye Eski Sovyet Bloğu ülkelerinden ev işçiliği iş kolunda çalışmak için göç etmiş kadınların içerisinde yer aldıkları sosyal, siyasal, kültürel ve ekonomik koşulların ortaya çıkarılması, göçmen ev işçilerinin yaşadıkları süreçlerinin incelenmesi [14],

10. Göçmen inşaat işçilerinin yaşam ve çalışma alanların keşfedilmesi, yaralanmaları ve hastalıkları etkileyen sebeplerin incelenmesi, tedavi ve sağlık hizmeti modelinin bulunması, ekonomik yük ve tüm politika sonuçlarının ele alınması [15],

11. Göçmen işçilerin Finlandiya'daki İş Sağlığı ve Güvenliği hizmetleri beklenti ve deneyimlerinin ortaya konmas1 [16],

12. Sosyoekonomik ve politik boyutları ile, işçilerin işgücü piyasasında kırılganlıklarına neden olan kişisel faktörleri göz ardı etmeden, hukukun ve yasal kurumların göçmen işçilerin sorunlarına odaklanmasının amaçlanması [17],

13. Katar'da yaşayan Hint göçmen işçilerin sağlık durumlarını, yaşam koşullarını, çalışma ile ilgili sorunları, kazaları ve sağlık tesislerine erişimlerinin incelenmesi [18],

14. Göçmen işgücüne genel bir bakış, göçmenlerin çalışma koşullarını ve ISG risklerini belgeleyen anketlerden elde edilen veri tabanları endeksi geliştirilmesi [19],

15. Asya ekonomik entegrasyonu kapsamında kadın göçmen işçilerin durumunun, kapsayıcı ve kalkınma vizyonuyla daha iyi anlamanın amaçlanması [20],

16. Çin'de, gelişen İş Sağlığı ve Güvenliği (İSG) rejimleri altında göçmen işçilerin korunması konusundaki araştırmaların raporlanması [21],

17. Göçmen işçilerin, tehlikelere maruz kalma ve işyerinde güvenli çalışmaya erişim, İSG, işçi hakları bilinci, mültecilerin İSG kırılganlığına neden olan faktörlerin araştırılması [22],

18. Göçmen çalışanların İSG ile ilgili deneyimlerinin anlaşılmasına katkıda bulunmak ve üç ana kısıtlamanın önemini vurgulamak: işverenlerine bağımlılık ile ilişkili zorluklar, iş sözleşmelerinin gerçek çalışma koşulları ile arasındaki farklar ve bu sözleşmeleri uygulamak ve Kanada'daki göçmen işçilerin entegrasyon seviyelerinin yükseltilmesi [23],

19. Göçmen işçiler dahil olmak üzere, kuruluşundan bugüne ILO'nun (Uluslararası Çalışma Örgütü) İş Sağlığı ve Güvenliği uygulamalarına yüz yıllık bakış [24],

20. Göçmen tarım işçilerinin İş Sağlığı ve Güvenliği konusundaki öznel deneyimlerinin açığa çıkarılması ve genel idari sorunların saptanması [25].

Yukarıda açıklanan çalışmalar, kesitsel ve uzunlamasına nitel, nicel ve karma metodolojiler kullanılarak yapılmışlardır. Örneklem olarak kolay ulaş1labilir, basit tesadüfi, kartopu, küme ve amaçlı örneklem metotları kullanılmıştır. Veri toplamada anket, yarı yapılandırılmış bireysel, grup ve odak grup görüşmeler, etnografik gözlem ve literatür tarama yöntemleri kullanılmıştır. Kullanılan analiz yöntemleri, karşılaştırma, istatiksel regresyon, ampirik veri, sosyal ağ, tematik içerik, cinsiyet, naratif analiz yöntemleridir. Yapılan analizlerde, Haddon Matrisi, Stata, SPSS, Excel, Nvivo gibi bilgisayar programları kullanılmıştır. İncelenen 20 çalışma göstermiştir ki;

1. Gelişmemiş, gelişmekte olan ve gelişmiş tüm ülkelerde, ölümlü ve yaralanmalı iş kazaları ile meslek hastalıkları benzer İş Sağlığı ve Güvenliği endişeleri ve risk modelleri göstermektedir; veriler kabul edilebilir sınırların çok üzerindedir ve müdahale gerektirmektedir;

2. Belirli bölgelerdeki savaşlar ve dünyadaki gelir dağılımı dengesizliğinin yol açtığı düzensiz göçler, kargaşaya neden olmakta ve en sorunlu göçmen türü olan, kontrol edilemeyen, veri toplamada zorlanılan kayıt dışı göçmenlerin artmasına sebep olmaktadırlar;

3. Yerlilerle karşılaştırıldığında, göçmen işçiler, bedenen çalışma veya düşük vasıflı iş kollarında yoğunlaşmışlardır, geçici veya kayıt dışı istihdam ve düşük ücretler ile istihdam edilmektedirler, işte ayrımcılık; daha yüksek fiziksel talepler, uzun süreli çalışmalar, daha kötü çevresel çalışma koşulları ve özellikle ergonomik ve psikososyal tehlikeler gibi mesleki risklere daha fazla maruz kalma; cinsel ve etnik tacizlere maruziyetleri kabul edilemez boyutlardadır.

4. Bulgularımız, uluslararası göçmen işçiler arasında çalışma koşullarını ve İş Sağlığı ve Güvenliği sonuçlarını araştıran önceki incelemelerle uyumludur.

Çalışmaların içeriklerinde bazı eksikler tespit edilmiştir. Örneğin; 
1. Birçok sorun vurgulanmış, ancak ya çözüm önerilmemiş ya da yetersiz çözümler önerilmiştir. İşyerindeki göçmen işçiler arasında işle ilgili yaralanmaların ve hastalıkların kanıta dayalı olarak önlenmesinin yanı sıra, sağlık politikası yapıcılarını daha iyi bilgilendirmek için çok yararlı olabilecek hiçbir müdahale ve öneri çalışması mevcut değildir.

2. Göçmen çalışan, işveren, kanun yapıcı ve uygulayıcıların ilişkilerini ve gelişmeleri uzun soluklu inceleyen, sonuçlarını karşılaştıran yararlı olabilecek hiçbir müdahale ve öneri çalışması mevcut değildir.

3. Göçmen işçiler arasında, İş Sağlığı ve Güvenliği çıktılarının bu denli olumsuz bir tablo oluşturmasında göç yolları ve göçmenlerin oynadığı potansiyel rol daha fazla çalışılmalıdır (belgelenip belgelenmemiş olması, sığınmacılar, geçici koruma altındakiler, uluslararası koruma altındakiler).

Çalışmamıza makalelerin yanı sıra, gri literatürü (örneğin konferans özetleri veya bildirileri, tezler, tezler, kitaplar veya kitap bölümleri) de dahil ettik. Ancak, yayınlanan bazı belgeleri gözden kaçırmış olabiliriz. Çalışmalar arasında örneklem büyüklüğü ve farklılıkları, veri toplama yöntemleri ve hem çalışma koşullarını hem de İSG sonuçlarını değerlendirme yöntemleri açısından farklılıklar gözlenmiştir. $\mathrm{Bu}$ heterojeni, bulguları karşılaştırma ve birleştirme yeteneğimizi kısıtladı. Bu nedenle, sunulan sonuçlar sadeleştirme, özet ve mevcut bilgilerin seçimidir.

Önceki incelemelerle ilgili olarak, bu makale aşağıdaki güçlü yönlere sahiptir:

- Gerçekleştirilmiş nicel, nitel ve karma çalışmaların güncel ve kapsamlı sonuçlarını sunar;

- Mülteciler ve sığınmacılar da dahil tüm göçmen işçilerle ilgilenir;

- Seçilen çalışmalar, kalkınmışlık ölçeğinde gelişmemiş, gelişmekte olan ve gelişmiş ulusları kapsar ve sanıldığının aksine, gelişmiş ülkelerin de ciddi İSG uygulama sorunları olduğunu gösterir.

\section{SONUÇLAR (CONCLUSIONS)}

$\mathrm{Bu}$ kapsam belirleme incelemesinin bulguları, göçmen işçiler arasındaki olumsuz İş Sağlığı ve Güvenliği sonuçlarının, müdahaleci yaklaşımla ele alındığından emin olmak için küresel iş birliğine güçlü bir şekilde ihtiyaç olduğunu göstermektedir. Ayrıca, göçmen çalışanların sağlık hizmetlerine adil erişimi için güçlü ve çok disiplinli bir çalışmanın yapılması gerektiğine inanıyoruz. Göç, daha fazla dikkat gerektiren, artan küresel sorunlar zincirinin önemli bir bölümünü temsil etmektedir. Bu nedenle, İş Sağlığı ve Güvenliği risklerini önlemeye yönelik tedbirler almak ve gelişmeleri izleyebilmek için somut ve kanıta dayalı bir uygulama yaklaşımı gerekecektir. İş sağlığı ve güvenliği açısından aşağıdaki kilit eylemlere ihtiyaç vardir:

1. Odaklanmış ve çok disiplinli risk değerlendirmeleri yoluyla, göçmen işçilerin refahının sağlanması ve işyerlerinde sağlık sorunlarının önlenmesi,

2. Mümkün olan azami ölçüde erişilebilir sağlık gözetimi, işe uygunluk, vaka yönetimi ve deneyimli, hesap verebilir ve motivasyonu yüksek bir işyeri hekimi tarafından gerçekleştirilen iş sağlığı teşviki ve geliştirilmesi yoluyla göçmen işçilerin sağlık ihtiyaçlarına somut ve zamanında çözümler getirilmesi,

\section{Pratisyen hekimlerle daha işbirlikçi diyalog,}

4. Genel olarak göçmen işçilerde ve özellikle kadın ev işçileri ve bakıcılar için işle ilgili olumsuz uygulamalar ve cinsel taciz için daha fazla sosyal koruma ve tazminat hakları,

5. Göçmen işçilerin İş Sağlığı ve Güvenliği ile ilgili mevcut koruyucu önlemlere ilişkin mevzuat, işyerlerinde düzenli ve proaktif uygulanmalı, izlenmelidir,

6. Göçmen işçilere, özellikle düzensiz göçmen işçilere kamu iş sağlığı hizmetlerine ücretsiz erişim sağlanmalıdır.

7. Eşit işe eşit ücret ve angarya sorunları yakından takip edilmeli, uzun süreli çalışmalara karşı göçmen işçiler korunmalıdır.

Yukarıda önerilen en iyi uygulamaların, kurumsal sosyal sorumluluk ilkelerine göre ve göçmen nüfus için daha genel bir sosyal koruma ve sağlık sistemleri tasarımı çerçevesinde benimsenmesi; göçmen işçilerin etkili entegrasyonu, işçiler, işletmeler ve genel olarak toplum için faydaları vardır. Son olarak, gelecekteki araştırmalar; işgücü piyasası kurumları, cinsiyet, dil, göçmen akımları ve göçmen işçiler arasında İş Sağlığı ve Güvenliği çıktıları oluşturacak kurumlar olarak daha derin analizler yapılmasını amaçlamalıdır. 


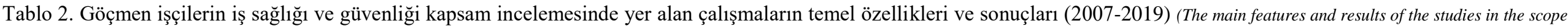
of occupational health and safety of immigrant workers (2007-2019))

\begin{tabular}{|c|c|c|c|c|c|c|c|}
\hline NO & YAZAR & ÜLKE & TARÍH & AMAÇ/HEDEF & YÖNTEM, ÖRNEK & $\begin{array}{c}\text { ANAHTAR } \\
\text { KELIMELER }\end{array}$ & GENEL SONUÇLAR-ÖNERILER \\
\hline 1 & Wyckoff ve ark & A.B.D. & 2007 & $\begin{array}{l}\text { Mesleki yaralanma riskini } \\
\text { azaltmak için gerekli } \\
\text { eğitimlerin verilmesi, durum } \\
\text { değerlendirilmesi ve } \\
\text { süreklilik sağlanması. }\end{array}$ & $\begin{array}{l}\text { Karma metot, Camp } \\
\text { survey, Yarı } \\
\text { Yapılandırılmış } \\
\text { Görüşme, Anket, } \\
\text { Haddon Matrisi. Odak } \\
\text { Gruplar 5, Anket 29, } \\
\text { Görüşme } 45 \text { kişi ile } \\
\text { yapıldı. }\end{array}$ & $\begin{array}{l}\text { Göçmen iş̧̧iler, } \\
\text { katılımcı araştırma, } \\
\text { müşterek araştırma, } \\
\text { iş güvenliği, sağlık, } \\
\text { topluluk } \\
\text { değerlendirmesi }\end{array}$ & $\begin{array}{l}\text { Yedi katılımcıdan beşi (\%71) işe alım sürecinden çok memnun kaldı. } \\
\text { Ölümlü iş kazası oranı yılda } 100.000 \text { iş̧̧i başına } 22,7 \text { ile tarım ABD'nin } \\
\text { en tehlikeli endüstrileri arasındadır. Kuzey Carolina, Ohio ve Güney } \\
\text { Carolina'daki tarım iş̧̧ilerinin iş sağlığı ile ilgili araştırmalar, kamp } \\
\text { anket yöntemlerine göre ortalama } \% 8,4 \text { yaralanma oranları tespit etti. } \\
\text { Mevsimlik işgücü kabaca } \% 45 \text { İspanyol, } \% 45 \text { Yerli Amerikalı ve\%10 } \\
\text { Anglo veya beyazdır. }\end{array}$ \\
\hline 2 & $\begin{array}{l}\text { Shaghayegh } \\
\text { Yousefi }\end{array}$ & Kanada & 2007 & $\begin{array}{l}\text { Mevsimlik Meksikalı tarım } \\
\text { işçileri çalıştıran İngiliz } \\
\text { Kolombiyalı çiftçilerin İş̧ } \\
\text { Sağllğı ve Güvenliği ve } \\
\text { barınma sorunları. }\end{array}$ & $\begin{array}{l}\text { Nitel kesitsel metot, } \\
\text { Vaka çalışması } \\
358 \text { Anket } \\
53 \text { yarı yapılandırılmış } \\
\text { görü̧sme, } \\
\text { Karşıllaştırmalı Analiz. }\end{array}$ & $\begin{array}{l}\text { Geçici mevsimlik } \\
\text { tarım işçileri, iş } \\
\text { sağlığı ve güvenliği } \\
\text { düzenlemeleri, } \\
\text { barınma yönergeleri, } \\
\text { British Columbia }\end{array}$ & $\begin{array}{l}\text { Meksikalı tarım işçilerinin } \% 80 \text { konuta erişim sorunu var. Eğitimlerde } \\
\% 37,5 \text { çalışan dil sorunu yaşıyor. } \\
\text { Çalısanları \% } \% \text { 'i hasat dönemi İSG uygulamalarının yapılmadığını } \\
\text { söylüyor. } \\
\text { Tarımda çalışan yabancı işçiler toplam işçilerin\% } \% 77 \text { 'si, bunların \%75'i } \\
\text { de Meksikalıdır. } \\
\text { işçilerinin \%53'üu yasal statü kazanamamıştır. }\end{array}$ \\
\hline 3 & $\begin{array}{l}\text { İngiltere izleme } \\
\text { komisyonu }\end{array}$ & İngiltere & 2007 & $\begin{array}{l}\text { İngiltere'deki göçmen } \\
\text { iş̧ilerin İSG koşullarının } \\
2007 \text { yll için takibi. }\end{array}$ & $\begin{array}{l}\text { Karma metot, } \\
\text { Literatür Taraması, } \\
\text { Odak grup görüşme, } \\
\text { istatistiksel analiz }\end{array}$ & $\begin{array}{l}\text { Göçmen işçiler, } \\
\text { izleme, eğitim, } \\
\text { iletişim, barınma, } \\
\text { entegrasyon }\end{array}$ & $\begin{array}{l}\text { Londra'da göçmenlerce kiralanan konutların yüzde } 10 \text { 'u aşırı kalabalık } \\
\text { ve bu hızla artıyor. Cornwall'da karavanlarda yaklaşık } 3.000-4.000 \\
\text { yabancı iş̧i yaşıyor. Bu azınlık grubu konut, okul ve sağlık için } 174 \\
\text { milyon sterlin bağış toplanmıştır. }\end{array}$ \\
\hline 4 & K. Lee ve ark. & $\begin{array}{l}\text { Avustralya, } \\
\text { Kore, } \\
\text { Malezya, } \\
\text { Singapur, } \\
\text { Tayland }\end{array}$ & 2011 & \begin{tabular}{|l|} 
Beş Asya ve Pasifik \\
ülkesindeki (Avustralya, Kore \\
Cumhuriyeti, Malezya, \\
Singapur ve Tayland) göçmen \\
iş̧iler için iş güvenliğinin \\
iyileştirilmesi konusundaki \\
artan endişeye yanıt olarak İş̧ \\
Sağlığı ve Güvenliği (ISGG) \\
koşullarını incelemektir \\
\end{tabular} & $\begin{array}{l}\text { Nitel meto7, literatür } \\
\text { taramas1. }\end{array}$ & $\begin{array}{l}\text { Göçmen işçiler, iş } \\
\text { sağlığı ve güvenliği, } \\
\text { Asya }\end{array}$ & 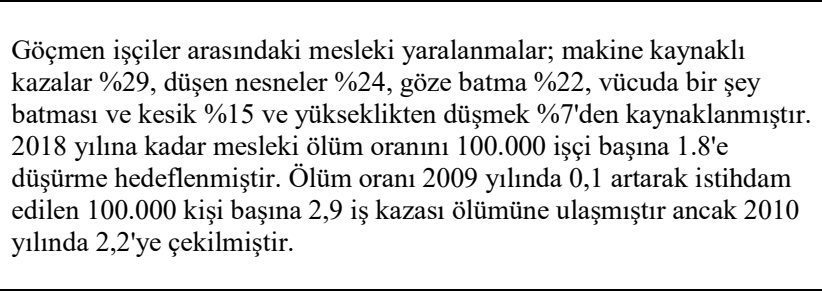 \\
\hline 5 & Qiujie Zhang & Çin & 2012 & $\begin{array}{l}\text { Bireysel faktörlerin, mesleki } \\
\text { eğitimin ve çalışmanın } \\
\text { göçmen işçilerin mesleki } \\
\text { yaralanmaları üzerindeki } \\
\text { etkisini belirlemek }\end{array}$ & $\begin{array}{l}\text { Nicel Kesitsel metot, } \\
\text { Kolay ulaşlabilir } \\
\text { örneklem, Anket, } \\
\text { Lojistik Regresyon } \\
\text { analizi, Stata } 10 \\
560 \text { anket } \\
\text { Guangzhou'dan } 241, \\
\text { Pekin'den 194, } \\
\text { Wuxi'den 125. }\end{array}$ & $\begin{array}{l}\text { İş kazası, Göçmen } \\
\text { iş̧iler, Mesleki } \\
\text { eğitim, İs sözleşmesi }\end{array}$ & 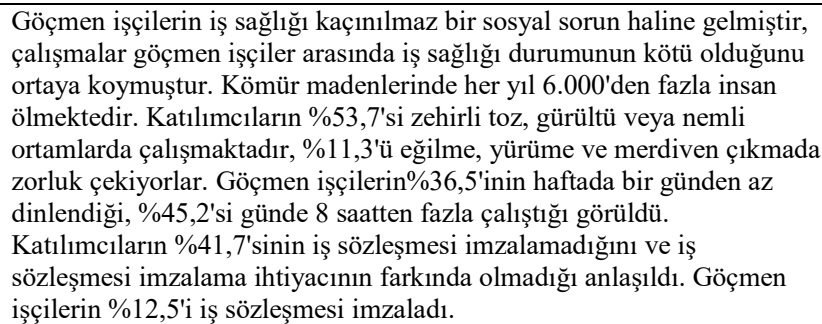 \\
\hline
\end{tabular}


Tablo 2. Devam (Continue)

\begin{tabular}{|c|c|c|c|c|c|c|c|}
\hline 6 & Arcury ve ark. & A.B.D. & 2013 & $\begin{array}{l}\text { Tarım, ormancılık ve balıkçılık } \\
\text { sektörlerinde mesleki } \\
\text { maruziyetleri, veri } \\
\text { sinılamalarını, göçmen işçilerin } \\
\text { özelliklerini, göçmen iş̧ilere } \\
\text { yönelik endişe nedenlerini, } \\
\text { incelemek }\end{array}$ & $\begin{array}{l}\text { Nitel Kesitsel metot, } \\
\text { çalışma konferans1, } \\
\text { literatür tarama }\end{array}$ & $\begin{array}{l}\text { Göçmen işçiler, } \\
\text { tarım, ormancılık, } \\
\text { balıkçlık, sağlık } \\
\text { sorunları, azınlık } \\
\text { sağlığı }\end{array}$ & $\begin{array}{l}\text { ABD'nin güneydoğusundaki } 123.122 \text { çiftlikten } 14.195 \text { çiftlik sözleşmeli } \\
\text { gö̧çmen iş̧̧i istihdam ettiğini bildirdi. Göçmen iş̧ilerin \%35'i hiç } \\
\text { İngilizce bilmemektedir. Çiftlik iş̧ilerinin dörtte birinin aile gelirleri } \\
\text { yoksulluk sınırının altında. Çocuk işçiliğ̈i, özellikle tarım için önemli bir } \\
\text { husustur. Mevcut düzenlemeler } 12 \text { yaşından küçük çocukların } \\
\text { (ebeveynlik izni ile } 10 \text { yaş) resmi olarak tarımda istihdam edilmesine } \\
\text { izin vermektedir. Yaralanma ve hastallk insidans oranı } 4 \text {,9'dur. Tarım, } \\
\text { balıkçlık ve ormancllık Sektörü yılllık istihdamın \%1'inden daha azını } \\
\text { oluștursa da mesleki ölümlerin \%13'ü bu Sektörlerde yaşanmaktadır. }\end{array}$ \\
\hline 7 & Svensson ve ark & Genel & 2013 & $\begin{array}{l}\text { Kapsamlı bir literatür taraması } \\
\text { yaparak tarımdaki göçmen } \\
\text { işçilere ilişkin mevcut bilgileri } \\
\text { derlemeyi amaçlamaktadır }\end{array}$ & $\begin{array}{l}\text { Nitel Uzunlamasına } \\
\text { metot, Literatür } \\
\text { Tarama, Hakemli } \\
\text { Dergiler İnceleme, } \\
390 \text { çalış̧ma }\end{array}$ & $\begin{array}{l}\text { Göç, tarım, göçmen } \\
\text { iş̧̧i sağlığı, insan } \\
\text { hakları ve göç, Tarım } \\
\text { ilacı, mesleki } \\
\text { yaralanmalar, } \\
\text { göçmen Tarım } \\
\text { işçileri. } \\
\end{array}$ & $\begin{array}{l}\text { Göçmen çiftçilerin işgücü, sağlık, psikososyal ve ücret koşulları ile } \\
\text { ilgili araştırma eksikliğine dikkat çekildi. Göçmen tarım iş̧ilerinin } \\
\text { karşlaş̧tı̆ı sorunların çok boyutlu olduğu ve göçmen iş̧i sorunlarının } \\
\text { ele alınması için hem politika geliştirmeye hem de daha fazla } \\
\text { araştırmaya ihtiyaç olduğu saptand. }\end{array}$ \\
\hline 8 & $\begin{array}{l}\text { Srinivasan S. ve } \\
\text { Ilango P. }\end{array}$ & $\begin{array}{l}\text { Hindistan, } \\
\text { Thamil Nadu }\end{array}$ & 2013 & $\begin{array}{l}\text { Thamil Karur bölgesinde } \\
\text { Thogamalai maden ocaklarında } \\
\text { çalışan gö̧çmen kadın işçilerin } \\
\text { İş Sağlığı ve Güvenliği } \\
\text { sorunları. }\end{array}$ & $\begin{array}{l}\text { Nicel Kesitsel } \\
\text { metot, Vaka } \\
\text { çalışması, Basit } \\
\text { tesadüfi Örneklem, } \\
200 \text { kadın göçmen } \\
\text { işçi ile Yarı } \\
\text { yapilandırılmış } \\
\text { görüşme, literatür } \\
\text { taraması, SPSS }\end{array}$ & $\begin{array}{l}\text { Meslek, Sağlık, Göç, } \\
\text { Kadın göçmen } \\
\text { çalışan, Taciz. }\end{array}$ & 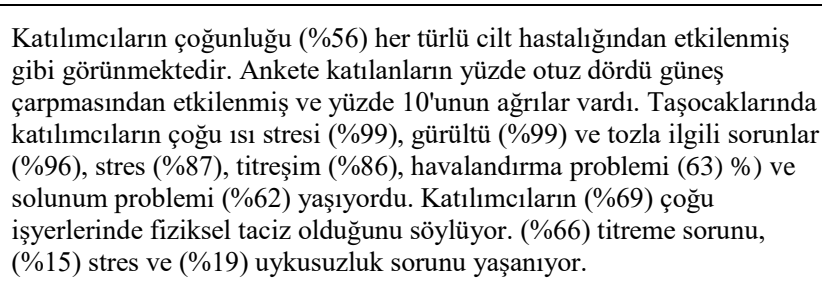 \\
\hline 9 & A. E. Akalın & Türkiye & 2014 & $\begin{array}{l}\text { Türkiye'ye Eski Sovyet Bloğu } \\
\text { ülkelerinden ev işçiliği iş } \\
\text { kolunda çalışmak için gö̧ etmiş } \\
\text { kadınların içerisinde yer } \\
\text { aldıkları sosyal, siyasal, kültürel } \\
\text { ve ekonomik koşulları ortaya } \\
\text { çıarılması, göçmen ev } \\
\text { iş̧ilerinin yaşadıkları süreçleri } \\
\text { incelemek. }\end{array}$ & $\begin{array}{l}\text { Nitel Kesitsel metot, } \\
\text { Kartopu örnekleme, } \\
48 \text { çalışan ile Yarı } \\
\text { yapılandırılmış } \\
\text { görüşme, } 10 \text { işveren } \\
\text { ile yapılandırılmış } \\
\text { görüşme, sosyal ağ } \\
\text { analizi, Excel }\end{array}$ & $\begin{array}{l}\text { Uluslararası Göç, } \\
\text { Göçün Kadınlaşması, } \\
\text { Ev İşçiliği, Göçmen } \\
\text { Ev İsçiliği, Ulus- } \\
\text { Ötesi Sosyal Ağlar }\end{array}$ & 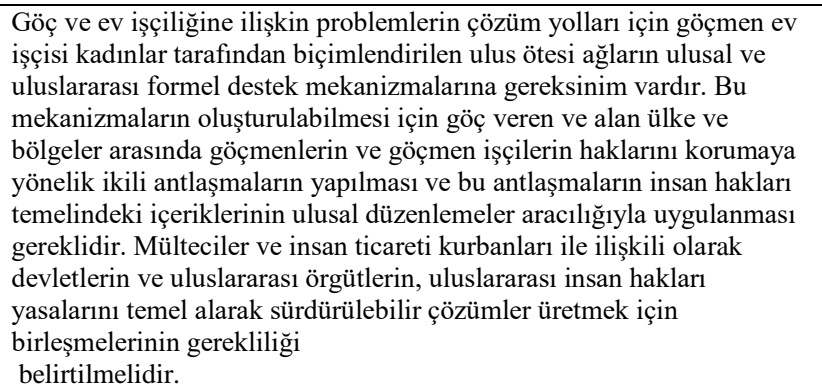 \\
\hline 10 & M. Akram & $\begin{array}{l}\text { Hindistan, } \\
\text { Western Uttar } \\
\text { Pradesh }\end{array}$ & 2014 & $\begin{array}{l}\text { Göçmen inşaat işçilerinin } \\
\text { yaşam ve çalışma alanlarını } \\
\text { keşfetmek, yaralanmaları ve } \\
\text { hastalıkları etkileyen sebepleri } \\
\text { incelemek, tedavi ve sağllk } \\
\text { hizmeti modelini bulmak, } \\
\text { ekonomik yükü ve tüm politika } \\
\text { sonuçlarını ele almak. }\end{array}$ & $\begin{array}{l}\text { Nicel kesitel metot, } \\
\text { Küme Örneklemesi, } \\
149 \text { erkek, } 151 \\
\text { kadın ile yapılan } \\
\text { Yarı Yapıllandırılmış } \\
\text { görüşme, Etnografik } \\
\text { Gözlem }\end{array}$ & $\begin{array}{l}\text { Göçmen inşaat } \\
\text { işçileri, meslek } \\
\text { hastalığı, halk } \\
\text { sağlığı, sağlıksızlık }\end{array}$ & $\begin{array}{l}\text { Çalışanların \%84'ü bambu kulübelerde yaşıyor, yarıdan fazlası katı } \\
\text { besin alamıor, \%80'i kuyu suyu içiyor, çalışanların \%35'i son bir yılda } \\
\text { en az bir kaza geçirmiştir, kazalarda el, kol kırılma oranı } \% 5 \text {. kadınların } \\
\% 85 \text { 'i, erkeklerin \% } \% 55 \text { 'i öksürük, mide ağrısı, solunum zorluğu gibi } \\
\text { hastalıklar yaşamaktadırlar. } 300 \text { kişiden yedisi (yüzde } 2,3 \text { ) tüberküloz } \\
\text { geçirmiştir. }\end{array}$ \\
\hline
\end{tabular}


Tablo 2. Devam (Continue)

\begin{tabular}{|c|c|c|c|c|c|c|c|}
\hline 11 & L. O. Apondi & Finlandiya & 2015 & $\begin{array}{l}\text { Göçmen işçilerin } \\
\text { Finlandiya'daki iş sağlığ } 1 \\
\text { hizmetleri beklentilerini ve } \\
\text { deneyimlerini ortaya koymak }\end{array}$ & $\begin{array}{l}\text { Nitel kesitsel metot, } \\
\text { Kartopu örnekleme, } \\
\text { Amaçlı Örneklem, } \\
12 \text { Yarı } \\
\text { yapılandırılmış Yüz } \\
\text { Yüze Görüşme, } \\
\text { Tematik İçerik } \\
\text { Analizi }\end{array}$ & $\begin{array}{l}\text { Sağlık sektörü, } \\
\text { göçmen iş̧̧i, mülteci, } \\
\text { sağlık, sağllk } \\
\text { hizmetleri, }\end{array}$ & $\begin{array}{l}\text { Göçmen işçilerin İş Sağlığı ve Güvenliği hizmetlerine erişiminde } \\
\text { karşılaştıkları zorluklar baş edilmez ve çok yönlüdür. Sağlık } \\
\text { hizmetlerinin göçmen nüfusa erişimini arttırmaya yönelik çabalar, } \\
\text { göçmen işçilerin refahını da artıracaktır, bu hedefe ulaşmak için, mevcut } \\
\text { entegrasyon programlarının geliştirilmesi gereklidir. Ortak dilin rolü } \\
\text { asla inkâr edilemez. Göçmen nüfusun dil becerileri ile donatılması } \\
\text { bilgiye ulaşmalarını kolaylaştırır ve İSG hizmetlerine erişilebilirliği } \\
\text { artırır. }\end{array}$ \\
\hline 12 & İ. İ. Salih & İngiltere & 2015 & $\begin{array}{l}\text { Sosyoekonomik ve politik } \\
\text { boyutu ile işçilerin işgücü } \\
\text { piyasasında kırılganlıklarına } \\
\text { neden olan kişisel faktörleri göz } \\
\text { ardı etmeden, hukukun ve yasal } \\
\text { kurumların göçmen işçilerin } \\
\text { sorunlarına bakışı ve tutumuna } \\
\text { odaklanmayı amaçlamaktadır }\end{array}$ & $\begin{array}{l}\text { Nitel kesitsel metot, } \\
\text { Etnografik } \\
\text { Fenomenoloji, } \\
\text { Kartopu örnekleme, } \\
30 \text { işveren, } 7 \text { ev } \\
\text { çalşsanı kadın ve 1 } \\
\text { erkek çalış̧anla Yarı } \\
\text { Yapıılandırılmış } \\
\text { Görüşme, içerik } \\
\text { analizi yöntemi, } \\
\text { Nvivo 10 }\end{array}$ & $\begin{array}{l}\text { Göçmen ev işçileri, } \\
\text { mülteci, ISG, kırılgan } \\
\text { gruplar, iş hukuku, }\end{array}$ & $\begin{array}{l}\text { Bazı işverenler, ev işçilerinin kırılganlıklarından yararlanmaktadır, } \\
\text { çünkü yasalar buna izin vermektedir. İşverenler, ev işçilerinin sağlık ve } \\
\text { güvenliği konusunda endişelenmek zorunda değildir, çünkü hane } \\
\text { halkları sağlık ve güvenlik yasasından muaftır. Ayrıca, iş kanunu, } \\
\text { işverenlerin ev işçilerine sürekli olarak asgari ücrete göre ödeme } \\
\text { yapmalarına izin veriyor. }\end{array}$ \\
\hline 13 & A. Bener & Katar & 2017 & $\begin{array}{l}\text { Katar'da yaşayan Hint göçmen } \\
\text { işçilerin sağlık durumlarını, } \\
\text { yaşam koşullarını, çalışma ile } \\
\text { ilgili sorunları, kazaları ve } \\
\text { sağlık tesislerine erişimini tespit } \\
\text { etmektir. }\end{array}$ & $\begin{array}{l}\text { Nicel kesitsel metot, } \\
\text { basit tesadüfi } \\
\text { örnekleme, } 1186 \\
\text { Anket, SPSS, Çoklu } \\
\text { Regresyon Analizi }\end{array}$ & $\begin{array}{l}\text { Sağlık hizmetlerine } \\
\text { erişim; sağlık } \\
\text { durumu, yaşam tarzı, } \\
\text { göçmen iş̧̧iler, } \\
\text { güvenlik }\end{array}$ & 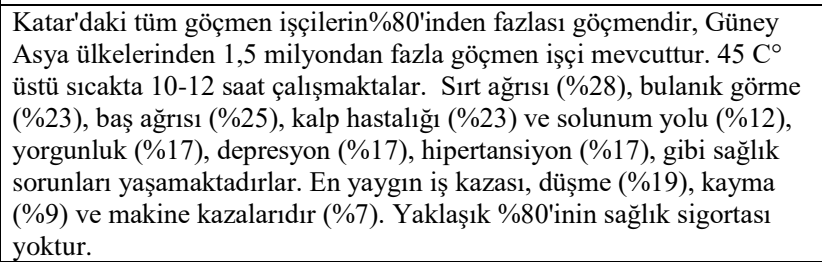 \\
\hline 14 & $\begin{array}{l}\text { M. A. Busque ve } \\
\text { ark. }\end{array}$ & Kanada & 2017 & $\begin{array}{l}\text { Göçmen işgücüne genel bir } \\
\text { bakış sunmak, göçmenlerin } \\
\text { çalı̧ma koşullarını ve İSG } \\
\text { risklerini belgeleyen } \\
\text { anketlerden elde edilen veri } \\
\text { tabanları endeksi geliştirmek. }\end{array}$ & $\begin{array}{l}\text { Nicel Uzunlamasina } \\
\text { metot, Literatür } \\
\text { tarama }\end{array}$ & İş Göçmen, Sağlık & $\begin{array}{l}\text { Literatürün gözden geçirilmesi, 2000-2003 yılları arasında yapılan } \\
\text { çalışmaların çoğunun, iş̧̧ilerin özelliklerini tanımladığını ve bazılarının } \\
\text { da işyeri özellikleri ve göçmenlerin genel sağlık durumu ile ilgili } \\
\text { olduğunu göstermektedir. Literatür analizi, işyerlerinde önleme } \\
\text { faaliyetlerini yönlendirmeye yardımcı olabilecek belirli anahtar } \\
\text { değişkenlerin (İkamet süresi, göçmen statüsü, meslek, ekonomik faaliyet } \\
\text { sektörü, eğitim ile ilgili faktörler ve işgücüne entegrasyon) } \\
\text { belirlenmesini sağlamıştır. }\end{array}$ \\
\hline 15 & $\begin{array}{l}\text { A. R. Torre ve } \\
\text { ark. }\end{array}$ & Endonezya & 2017 & $\begin{array}{l}\text { Asya ekonomik entegrasyonu } \\
\text { kapsamında kadın göçmen } \\
\text { işçilerin durumunu, kapsayıcı } \\
\text { ve kalkınma vizyonuyla daha } \\
\text { iyi anlamayı amaçlamaktadır. }\end{array}$ & $\begin{array}{l}\text { Karma metot, Vaka } \\
\text { Çalışması, Amaçlı } \\
\text { örneklem, } 85 \\
\text { derinlemesine } \\
\text { görüşme. } 640 \\
\text { Anket, Cinsiyet } \\
\text { Analizi, STATA }\end{array}$ & $\begin{array}{l}\text { Kadın göçmen iş̧̧i, } \\
\text { Asya, istihdam, eşit } \\
\text { ücret, İSG }\end{array}$ & $\begin{array}{l}\text { Göçmen kadın işçiler, bölgedeki } 14 \text { milyonluk toplam göçmen işçinin } \\
\text { (\%48)'ini olușturmaktadır, \%35'ine cinsel taciz uygulanmıştı, maaşları } \\
\text { aynı işi yapan yerli kadınların yarısı kadardır }\end{array}$ \\
\hline 16 & Mankui Li & Çin & 2017 & $\begin{array}{l}\text { Çin'de gelişen iş sağlığı ve } \\
\text { güvenliği (İSG) rejimleri altında } \\
\text { göçmen iş̧̧ilerin korunması } \\
\text { konusundaki araştırmaları } \\
\text { raporlamak. }\end{array}$ & $\begin{array}{l}\text { Nitel Uzunlamasına } \\
\text { metot, Literatür } \\
\text { taraması }\end{array}$ & $\begin{array}{l}\text { Göçmen işçiler, } \\
\text { korunma, ISG } \\
\text { rejimleri, katılım } \\
\text { hakları, sosyal } \\
\text { haklar. }\end{array}$ & $\begin{array}{l}\text { Göçmen işçilerin \%38'i yazılı iş sözleşmesi yapmıştır, \%46'sı kömür } \\
\text { madenciliği sektöründe meydana gelen } 12.554 \text { ölüm oranı var, kırsal ve } \\
\text { yabancı göçmen işçi sayısı } 274 \text { milyondur, kirli, tehlikeli ve alçaltıcı } \\
\text { işlerde çalışmaktadırlar. }\end{array}$ \\
\hline
\end{tabular}


Tablo 2. Devam (Continue)

\begin{tabular}{|c|c|c|c|c|c|c|c|}
\hline 17 & B. Yanar ve ark. & Kanada & 2018 & \begin{tabular}{|l|} 
Göçmen işçilerin, tehlikelere \\
maruz kalma ve işyerinde \\
güvenli çalışmaya erişim, ISG, \\
işçi hakları bilinci, mültecilerin \\
İSG kırıllganlığına neden olan \\
faktörler araştırlmıştır. \\
\end{tabular} & \begin{tabular}{|l|} 
Nitel kesitsel metot, \\
Basit tesadüfi \\
örnekleme, 18 Odak \\
grubu, 110 görüşme, \\
tematik içerik \\
analizi, NVivo \\
\end{tabular} & $\begin{array}{l}\text { İș sağllğ̆ ve } \\
\text { güvenliği kırılganlığı, } \\
\text { göçmen, iş, nitel }\end{array}$ & $\begin{array}{l}\text { Göçmen işçilerin \% } 25 \text { 'i ekonomik, \%35'i mülteci statüsündedir. } \\
\text { Güvenlik risklerinin farkında olmadan çalışmaya başladılar, çoğunun } \\
\text { birden fazla güvenlik açığı biçimi yaşadığı görülmektedir }\end{array}$ \\
\hline 18 & $\begin{array}{l}\text { L. Cedillo ve } \\
\text { ark. }\end{array}$ & Kanada & 2019 & $\begin{array}{l}\text { Göçmen çalış̧anların İSG ile } \\
\text { ilgili deneyimlerinin } \\
\text { anlaşılmasına katkıda } \\
\text { bulunmakta ve üç ana } \\
\text { kısııtlamanın önemini } \\
\text { vurgulamaktadır: işverenlerine } \\
\text { bağımlılık ile ilişskili zorluklar; } \\
\text { iş sözleşmelerinin gerçek } \\
\text { çalışsma koşulları ile arasındaki } \\
\text { farklar ve bu sözleşmeleri } \\
\text { uygulamak ve Kanada'daki } \\
\text { göçmen işçilerin entegrasyon } \\
\text { seviyelerini yükseltmek. }\end{array}$ & $\begin{array}{l}\text { Nitel kesitsel metot, } \\
\text { Saha çalışması, } \\
\text { Basit tesadüfi } \\
\text { örnekleme, } 99 \text { yarı } \\
\text { yapılandırılmış } \\
\text { görüşme, NVivo }\end{array}$ & $\begin{array}{l}\text { İşs sağllğı ve } \\
\text { güvenliği, geçici } \\
\text { yabancı iş̧̧iler, } \\
\text { düzenlenmesi, } \\
\text { Kanada, göç }\end{array}$ & $\begin{array}{l}\text { Geçici işgücü göçü, küresel olarak tüm göç hareketlerinin yaklașik } \\
\% 65 \text { 'ini oluşturmaktadır. Otel işçilerinin hizmet sektöründeki diğer } \\
\text { mesleklerden \% } 40 \text { daha fazla yaralanmalı kaza geçirdikleri } \\
\text { görülmektedir. İnşaat sektörü, dünyadaki en büyük ve en tehlikeli sanayi } \\
\text { sektörlerinden biridir. İşverene bağımlılık, güvenlik açığını artırır ve } \\
\text { çalışanın gücünü azaltır. }\end{array}$ \\
\hline 19 & $\begin{array}{l}\text { E. Wadsworth } \\
\text { ve David Walters }\end{array}$ & Genel & 2019 & $\begin{array}{l}\text { Göçmen işçiler dahil olmak } \\
\text { üzere, kuruluşundan bugüne } \\
\text { ILO'nun (Uluslararası Çalışma } \\
\text { Örgütü) İş Sağlığı ve Güvenliği } \\
\text { uygulamalarına yüz yılllk bakış. }\end{array}$ & $\begin{array}{l}\text { Nitel uzunlamasina } \\
\text { metot, Literatür } \\
\text { Taraması, yorum } \\
\text { analizi }\end{array}$ & $\begin{array}{l}\text { İSG, ILO, iş kazaları, } \\
\text { meslek hastalıkları, } \\
\text { afetler, katostrofik iş } \\
\text { kazaları. }\end{array}$ & $\begin{array}{l}\text { Dünya genelinde her gün iş̧̧ilerin \%5-7'si (1.000 kişi iş kazalarında, } \\
6500 \text { kişi meslek hastalıklarndan) güvensiz ve sağlıkşz çalışma } \\
\text { koşulları nedeniyle ölüyor. Tahminler, dolaşım sistemi hastalılarının } \\
\text { (yüzde 31), işle ilgili kanserlerin (yüzde 26) ve solunum hastalıklarının } \\
\text { (yüzde 17) toplam işle ilgili mortalitenin neredeyse dörtte üçüne katkıda } \\
\text { bulunduğunu göstermektedir. Hastalıklar, ölümle sonuçlanan iş } \\
\text { kazalarına kıyasla (ölümlerin yüzde } 13,7 \text { 'sini oluşturan) işle ilgili } \\
\text { ölümlerin (2,4 milyon ölüm \%86,3) büyük çoğunluğunun nedenidir. }\end{array}$ \\
\hline 20 & $\begin{array}{l}\text { C. S. Caxaj ve A. } \\
\text { Cohen }\end{array}$ & Kanada & 2019 & $\begin{array}{l}\text { Göçmen tarım işçilerinin iş } \\
\text { sağlığı ve güvenliği } \\
\text { konusundaki öznel } \\
\text { deneyimlerini açığa çıkarma ve } \\
\text { genel idari sorunlarını saptama. }\end{array}$ & $\begin{array}{l}\text { Nitel kesitsel metot, } \\
\text { anlatı yaklaşımı, } 127 \\
\text { odak grup } \\
\text { görüşmesi, naratif } \\
\text { analiz }\end{array}$ & $\begin{array}{l}\text { Geçici göçmen tarım } \\
\text { işçileri; mülteci, } \\
\text { mevsimlik tarımsal } \\
\text { işçi programı; iş } \\
\text { sağlığı ve güvenliği, } \\
\text { geçici yabancı işçi } \\
\text { programı, baskı, } \\
\text { Kanada }\end{array}$ & $\begin{array}{l}\text { İşçilerin \%44'ü işini kaybetmemek için hasta iken de çalışıyor, } \\
\text { çalışanların büyük bir kesimi zengin olmak ve ölmeden ülkelerine } \\
\text { dönmek istiyor. İşçilerin sağlıkl, tehlikesiz bir işyerinde çalşşma hakk1, } \\
\text { bunu sınırlandıran ve zayıflatan politik ve ekonomik düzenleyiciler } \\
\text { tarafindan hesaba katılmalıdır. }\end{array}$ \\
\hline
\end{tabular}




\section{ÇIKAR ÇATIŞMASI BİLDİRIMİ (CONFLICT OF INTEREST)}

Yazarlar tarafindan herhangi bir çıkar çatışması bildirilmemiştir.

\section{KAYNAKLAR (REFERENCES)}

[1] International Labour Organization (ILO), "Global Estimates on International Migrant Workers-Results and Methodology," ilo.org 05 December 2018. [online]. Available: https://www.ilo.org/global/publications/books/WCM S_652001/lang--en/index.htm [Accessed: 08 Jan. 2020].

[2] WHO Regional Office for Europe, "Report on the Health of Refugees and Migrants in the WHO European Region: no public health without refugee and migrant health," 2018, [online]. Available: https://www.inmp.it/pubblicazioni/WHO-

INMP_Health_Refugees_Summary.pdf [Accessed: 28 December 2019].

[3] International Labour Organization (ILO), "In search of decent work. Migrant workers' rights: A manual for trade unionists," ilo.org, 01 Jan 2008, [online].

Available: https://www.ilo.org/actrav/info/pubs/WCMS_115035 /lang--en/index.htm [Accessed: 08.Jan. 2020].

[4] İçişleri Bakanlığı, Göç İdaresi Genel Müdürlüğü. "İstatistikler". Erișim:14.02.2020. https://www.goc.gov.tr/.

[5] Türkiye İstatistik Kurumu (TÜİK). "Konularına göre istatistikler, nüfus ve demografi, istatistiksel tablolar ve dinamik sorgulama". Erişim: 14.02.2020. http://www.tuik.gov.tr/Start.do.

[6] L. A Wyckoff, G. E. Richardson, B.I. Santiago, "Identifying the Occupational Health Needs of Migrant Workers," Journal of Community Practice, vol. 15, no.3, pp. 57-76, October, 2007, doi: 10.1300/J125v15n03_04.

[7] S. Yousefi, "Improving health, safety and housing conditions of Mexican workers in BC: A farmer's perspective," Master Thesis, Simon Fraser University, British Columbia, Canada, 2007.

[8] Audit Commission U.K, “ Crossing borders: Responding to the local challenges of migrant workers,"www.auditcommission.gov.uk, January 2007. Available:

https://dera.ioe.ac.uk/6380/7/CrossingBorders_Redact ed.pdf. [Accessed: February 9, 2020].
[9] K. Lee, C. Mc Guinness, T. Kawakami, "Research on occupational safety and health for migrant workers in five Asia and the Pacific countries: Australia, Republic of Korea, Malaysia, Singapore and Thailand” U.S.A., ILO, 2011.

[10] Q. Zhang, "Occupational Injury Occurrence and Related Risk Factors among Chinese Migrant Workers," Procedia Engineering, vol. 43, pp.76-81, December, 2012, doi:10.1016/j.proeng.2012.08.014.

[11] T. A. Arcury, J. G. Grzywacz, J. Sidebottom, M. F. Wiggins, "Overview of Immigrant Worker Occupational Health and Safety for the Agriculture, Forestry, and Fishing (AgFF) Sector in the South Eastern United States," American Journal of Industrial Medicine, vol. 56, no. 8, pp. 911-24, August, 2013, doi: 10.1002/ajim.22173.

[12] M. Svensson, R. UrinboyevSvensson, A. Svensson, P. Lundqvist, "Migrant Agricultural Workers and Their Socio-Economic, Occupational and Health Conditions," A Literature Review. SSRN Electronic Journal, July, 2013, doi: 10.2139/ssrn.2297559.

[13] S. Vasan, I. Ponnuswami, A. Sahay, "Occupational Health Problems of Women Migrant Workers In Thogamalai, Karur District, Tamil Nadu, India," SSRN Electronic Journal, vol.2, no.2, pp. 1-7, February, 2013, doi: 10.2139/ssrn.2389346.

[14] A. E. Akalın, “Türkiye'de Ev Hizmetlerinde Çalışan Göçmen Kadınların Toplumsal ve İktisadi Varoluş Stratejileri Üzerine Sosyolojik Bir Analiz.," Doktora Tezi, Hacettepe Üniversitesi, Ankara, Türkiye, 2014.

[15] M. Akram, "Occupational Disease and Public Health Concerns of Migrant Construction Workers: A Social Epidemiological Study in Western Uttar Pradesh," Social Change, vol. 44, no. 1, pp. 97-117, February 2014, doi: https://doi.org/10.1177/0049085713514828.

[16] L. Apondi, "Migrant Workers' Perceptions, Expectations and Experiences of Occupational Health Services In Finland," Master Thesis, Tampere University Tampere, Finland, 2015.

[17] I. I. Salih, "The plights of migrant domestic workers in the UK: a legal perspective," $\mathrm{PhD}$ Thesis, Middlesex University. London, U. K., 2016

[18] A. Bener, "Health Status and Working Condition of Migrant Workers: Major Public Health Problems," International Journal of Preventive Medicine, vol. 8, 
September, 2017,

10.4103/ijpvm.IJPVM_396_16.

[19] P. Prud'homme, M. A. Busque, P. Duguay, D. Côté , "Immigrant Workers and OHS in Québec: State of Knowledge from Published Statistical Surveys and Available Data Sources," Institut de recherche Robert-Sauvé en santé et en sécurité du travail, January 2017, ISSN : 0820-8395.

[20]The ASEAN Secretariat Jakarta, "Women Migrant Workers in the Asian Economic Community," Thailand, U.N. Women, April 2017

[21] M. Li, "Protection for Migrant Workers under Evolving Occupational Health and Safety Regimes in China," Industrial Relations, vol. 72, no. 1, pp.56-75, April, 2017, doi:10.7202/1039590ar.

[22] B. Yanar, A. Kosny, P. M. Smith, “Occupational Health and Safety Vulnerability of Recent Immigrants and Refugees," International Journal of Environmental Research and Public Health, vol. 15, issue:9, September 2018, Doi: 10.3390/ijerph15092004.

[23] Codillo, Leonor; Lippel, Katherine; Nakache, Delphine. "Factors Influencing the Health and Safety of Temporary Foreign Workers in Skilled and LowSkilled Occupations in Canada," New Solutions: A Journal of Environmental and Occupational Health Policy, vol. 29, no. 3, pp. 422-458, August, 2019, doi: $10.1177 / 1048291119867757$.

[24] ILO, "Safety and Health at the heart of the Future of Work: Building on 100 years of experience," ilo.org. April 15 2019. [Online]. Available: https://www.ilo.org/safework/events/safeday/WCMS _686645/lang--en/index.htm. [Accessed: Feb. 04, 2020]

[25] C.S. Caxaj, A. Cohen, "I Will Not Leave My Body Here": Migrant Farmworkers' Health and Safety Amidst a Climate of Coercion," International Journal of Environmental Research and Public Health, vol. 16, no. 15, pp. 1-14, July, 2019, doi: 10.3390/ijerph16152643.

\section{Cengiz AKYILDIZ}

1982-1983 dönemi Yıldız Teknik Üniversitesi İnşaat Mühendisliği Bölümünü, 2015 Üsküdar Üniversitesi Sağlık Bilimleri Enstitüsü İş Sağlığı ve Güvenliği Tezli Yüksek Lisans bölümünü bitirmiş, İstanbul Ticaret Üniversitesi Fen Bilimleri Enstitüsü İş Sağlığı ve Güvenliği Bölümü Doktora öğrencisidir.

\section{İsmail EKMEKÇİ}

1980 yılında Yıldız Teknik Üniversitesi (IDMMA) Makine Mühendisliği Bölümünü bitirmiştir. 20032006 yılları arasında Sakarya Üniversitesi'nde Profesör olarak; 2006-2011 yılları arasında Marmara Üniversitesinde Prof. Dr. olarak görev yapmıştır. 2011 yılından bu yana da İstanbul Ticaret Üniversitesinde Prof. olarak çalışmaktadır. 2009-2010 yılları arasında Kırklareli Üniversitesi Teknik Eğitim Fakültesinde Dekanlık görevi; 2010-2011 tarihleri arasında Marmara Üniversitesi Teknik Bilimler Meslek Yüksek Okulu Müdürlügü̈; 2013-2014 yılları arasında İstanbul Ticaret Üniversitesi Uygulamalı Bilimler Fakültesi Dekanlık, 2017-2018 yıllarında İstanbul Ticaret Üniversitesi Mühendislik Fakültesi Dekanlık görevinde bulunmuştur. İş Güvenliği, Isı Tekniği, Enerji, Optimizasyon ve Sayısal Metotlar konularında çalışmaktadır.

\section{Hüseyin BAŞLIGİL}

İstanbul Üniversitesi Fizik Lisans (1970), İTÜ Kimya Mühendisliği (1978) mezunu. Doktorasını İstanbul Üniversitesinde yaptı. 1974- 2016 arasında Yıldız Teknik Üniversitesi Endüstri Mühendisliği Bölümü'nde çalıştı. Yöneylem Araştırması Anabilim Dalı Başkanlığ 1 ve Bölüm Başkanlığı yaptı. 2017'den beri Esenyurt Üniversitesi Endüstri Bölümünde çalışıyor. 